\title{
Temperature measurements of rabbit antral follicles
}

\section{J. Grinsted, K. Blendstrup*, M. P. Andreasen and Anne Grete Byskov}

The Finsen Laboratory, Strandboulevarden 49, 2100 Copenhagen $\emptyset$, and ${ }^{*}$ Department of Electrophysics, The Technical University of Denmark, Lundtoftevej, 2800 Copenhagen, DK-Denmark

\begin{abstract}
Summary. The temperature of 40 antral follicles in 16 rabbits was measured by microthermoelectrodes and by thermovision during anaesthesia. The temperature in the follicles was $2.8 \pm 0.2^{\circ} \mathrm{C}$ lower than the core body temperature and $1.4 \pm$ $0.2^{\circ} \mathrm{C}$ lower than in the ovarian stroma. No differences were observed between the temperatures obtained from large and small antral follicles, and different conditions of measurement gave similar results.
\end{abstract}

\section{Introduction}

The spermatogenic process in scrotal male mammals proceeds only if the temperature of the testis is lower than the core body temperature. If the temperature of the testis is raised to the core body level, the spermatocytes are arrested in late meiotic prophase (for review see VanDemark \& Free, 1970; Blackshaw, 1977). In the female the oocytes begin meiosis early in life but stop in late meiotic prophase, resting at this stage until the time of ovulation when the meiotic division is resumed.

No temperature difference between the environment of the female germ cell (the follicular fluid) and the core body has been detectable by conventional methods (for review see Cowles, 1965). A thermotelemetric investigation showed that the surface temperature of the ovary was lower than that of the rectum in the monkey (Balin, Busser, Fromm, Wan \& Israel, 1965). In the ewe the temperature of the stroma of the ovary containing the ovulating follicle was $0.2^{\circ} \mathrm{C}$ lower than that in the contralateral ovary. This study, using implanted thermistors, also showed that the temperature of the ovaries was $0.14^{\circ} \mathrm{C}$ (mean) higher than the core body temperature (Benoit, Borth, Ellicott \& Woolever, 1976).

However, ambient high climatic temperature correlates with impaired fertility in many female mammals, including women (for review see Waites, 1976).

In order to determine whether a temperature difference might exist between the antral follicles as they enlarge towards ovulation and the surrounding ovarian tissue and the core body, the temperature was measured in the ovary and other organs of rabbits with microthermoelectrodes.

\section{Materials and Methods}

Animals and surgery. Adult rabbits (about $3 \mathrm{~kg}$ ), Copenhagen White, Serum Institute, Copenhagen, were used. Two animals (Nos 2 and 8) were unstimulated, Rabbit 3 was mated 8-10 h before the start of the experiment (Table 1) and Rabbits 1, 4-7 and 9-16 were injected intramuscularly with $15 \mu \mathrm{g}$ Lutal (Hoechst), a synthetic gonadotrophin-releasing hormone with FSH/LH-RH activity, 8-10 h before the measurements. 
Table 1. Temperature measurements in large $(1,>2 \mathrm{~mm})$ and small $(\mathrm{s},<2 \mathrm{~mm})$ follicles of rabbits (see 'Methods' for experimental conditions)

\begin{tabular}{|c|c|c|c|c|c|c|c|c|}
\hline \multirow[b]{2}{*}{ Rabbit } & \multicolumn{2}{|c|}{ Follicle } & \multicolumn{6}{|c|}{ Temperatures $\left({ }^{\circ} \mathrm{C}\right)$} \\
\hline & $\begin{array}{l}\text { No. } \\
\text { (size) }\end{array}$ & $\begin{array}{l}\text { Temp. } * \\
\left({ }^{\circ} \mathrm{C}\right)\end{array}$ & Ovary $\dagger$ & Aorta & Psoas & $\begin{array}{l}\text { Core } \\
\text { body }\end{array}$ & $\begin{array}{c}\text { Follicle- } \\
\text { ovary }\end{array}$ & $\begin{array}{l}\text { Follicle- } \\
\text { core body }\end{array}$ \\
\hline \multirow[t]{5}{*}{1} & $1(1)$ & 36.45 & & & 38.42 & & & -1.97 \\
\hline & $2(s)$ & $38 \cdot 11$ & & & 38.69 & & & -0.31 \\
\hline & $3(s)$ & $38 \cdot 26$ & $38 \cdot 36$ & & $38 \cdot 80$ & $38 \cdot 42$ & -0.10 & $-0 \cdot 16$ \\
\hline & $4(1) \ddagger$ & 37.58 & & & $39 \cdot 18$ & & & -0.94 \\
\hline & $5(1)$ & $37 \cdot 52$ & & & $39 \cdot 58$ & & & -0.90 \\
\hline \multirow[t]{2}{*}{2} & $6(1)$ & $34 \cdot 39$ & $35 \cdot 30$ & \multirow{2}{*}{$38 \cdot 22$} & 38.47 & \multirow{2}{*}{$38 \cdot 22$} & -0.91 & -3.83 \\
\hline & $7(s)$ & 35.98 & $35 \cdot 32$ & & 38.47 & & -0.66 & $-2 \cdot 24$ \\
\hline \multirow[t]{3}{*}{3} & $8(1)$ & $35 \cdot 20$ & $\begin{array}{c}38 \cdot 51 \\
(38 \cdot 51)\end{array}$ & \multirow{3}{*}{39.83} & 39.73 & \multirow{3}{*}{39.83} & $-3 \cdot 31$ & $-4 \cdot 63$ \\
\hline & $9(\mathrm{~s})$ & $35 \cdot 17$ & $38 \cdot 22$ & & $39 \cdot 83$ & & -3.05 & $-4 \cdot 66$ \\
\hline & $10(s)$ & 34.98 & $38 \cdot 15$ & & $39 \cdot 83$ & & $-3 \cdot 17$ & $-4 \cdot 85$ \\
\hline \multirow[t]{6}{*}{4} & $11(\mathrm{~s})$ & $37 \cdot 70$ & & & 39.05 & \multirow{6}{*}{39.05} & & -1.35 \\
\hline & $12(1)$ & $37 \cdot 18$ & & & 39.15 & & & -1.87 \\
\hline & 13(l) & $36 \cdot 70$ & & & $39 \cdot 15$ & & & $-2 \cdot 35$ \\
\hline & $14(1)$ & $35 \cdot 95$ & & & $39 \cdot 15$ & & & $-3 \cdot 10$ \\
\hline & $15(1)$ & $36 \cdot 58$ & 37.55 & & 39.63 & & -0.97 & -2.47 \\
\hline & $16(s)$ & $34 \cdot 55$ & & & 39.63 & & & $-4 \cdot 50$ \\
\hline \multirow[t]{4}{*}{5} & $17(s)$ & $37 \cdot 38$ & $(39 \cdot 30)$ & & 40.45 & & & -2.92 \\
\hline & $18(\mathrm{l})$ & 37.28 & $38 \cdot 13$ & & 40.45 & $40 \cdot 30$ & -0.85 & -3.02 \\
\hline & $19(\mathrm{~s})$ & $37 \cdot 20$ & & & $40 \cdot 50$ & & & $-3 \cdot 10$ \\
\hline & $20(\mathrm{~s})$ & 37.09 & & & $40 \cdot 55$ & & & $-3 \cdot 21$ \\
\hline \multirow[t]{3}{*}{6} & $21(\mathrm{~s})$ & 35.40 & 36.03 & & 39.48 & \multirow{3}{*}{39.48} & -0.63 & -4.08 \\
\hline & $22(\mathrm{~s})$ & 36.90 & & & 39.50 & & & $-2 \cdot 58$ \\
\hline & $23(\mathrm{~s})$ & 36.78 & & & 39.55 & & & $-2 \cdot 70$ \\
\hline 7 & $24(s)$ & $35 \cdot 70$ & & & 38.58 & 38.58 & & $-2 \cdot 88$ \\
\hline \multirow[t]{2}{*}{8} & $25(\mathrm{~s})$ & 33.95 & 36.73 & 38.339 & & \multirow[t]{2}{*}{$38 \cdot 33$} & $-2 \cdot 78$ & $-4 \cdot 37$ \\
\hline & $26(\mathrm{~s})$ & 35.88 & 36.73 & $38.33 \%$ & & & -0.85 & -2.45 \\
\hline \multirow[t]{4}{*}{9} & $27(\mathrm{~s})$ & $36 \cdot 85$ & & \multirow{4}{*}{39.75} & 39.85 & \multirow{4}{*}{39.75} & & -2.90 \\
\hline & $28(s)$ & 35.40 & & & 39.95 & & & $-4 \cdot 35$ \\
\hline & $29(1)$ & 34.40 & 36.08 & & 39.93 & & -1.68 & $-5 \cdot 35$ \\
\hline & $30(1)$ & 35.78 & 36.08 & & 39.85 & & -0.30 & -3.97 \\
\hline 10 & $31(1)$ & 35.63 & & 39.08 & $39 \cdot 30$ & 39.08 & & -3.45 \\
\hline \multirow[t]{3}{*}{11} & $32(\mathrm{l})$ & $\begin{array}{c}36 \cdot 88 \\
(36 \cdot 88)\end{array}$ & $38 \cdot 32$ & & 39.22 & \multirow{3}{*}{39.00} & -1.44 & $-2 \cdot 12$ \\
\hline & $33(1)$ & $\begin{array}{c}36.49 \\
(36 \cdot 83)\end{array}$ & $38 \cdot 30$ & & $39 \cdot 12$ & & -1.81 & -2.51 \\
\hline & $34(1)$ & $\begin{array}{c}37.03 \\
(37.27)\end{array}$ & 38.44 & 39.00 & $39 \cdot 10$ & & -1.41 & -1.97 \\
\hline
\end{tabular}


Table 1.-Continued

\begin{tabular}{|c|c|c|c|c|c|c|c|c|}
\hline \multirow[b]{2}{*}{ Rabbit } & \multicolumn{2}{|c|}{ Follicle } & \multicolumn{6}{|c|}{ Temperatures $\left({ }^{\circ} \mathrm{C}\right)$} \\
\hline & $\begin{array}{l}\text { No. } \\
\text { (size) }\end{array}$ & $\begin{array}{l}\text { Temp. }{ }^{*} \\
\left({ }^{\circ} \mathrm{C}\right)\end{array}$ & Ovary $\dagger$ & Aorta & Psoas & $\begin{array}{l}\text { Core } \\
\text { body }\end{array}$ & $\begin{array}{c}\text { Follicle- } \\
\text { ovary }\end{array}$ & $\begin{array}{l}\text { Follicle- } \\
\text { core body }\end{array}$ \\
\hline 12 & $35(1) \S$ & $(35 \cdot 77)$ & $\begin{array}{c}37.47 \\
(36.89)\end{array}$ & $39 \cdot 60$ & 39.64 & 39.60 & & \\
\hline \multirow[t]{2}{*}{13} & $36(1)$ & $\begin{array}{c}37 \cdot 62 \\
(36 \cdot 89)\end{array}$ & $38 \cdot 26$ & & $39 \cdot 38$ & \multirow{2}{*}{$39 \cdot 30$} & -0.64 & -1.68 \\
\hline & $37(1)$ & $\begin{array}{c}36 \cdot 21 \\
(37 \cdot 74)\end{array}$ & $\begin{array}{c}37.96 \\
(38 \cdot 26)\end{array}$ & $39 \cdot 30$ & $39 \cdot 38$ & & -1.75 & -3.09 \\
\hline \multirow[t]{2}{*}{14} & $38(1)$ & $\begin{array}{c}37.04 \\
(37.53)\end{array}$ & $38 \cdot 31$ & & $39 \cdot 53$ & \multirow{2}{*}{39.48} & -1.27 & -2.44 \\
\hline & $39(1)$ & $\begin{array}{c}37.68 \\
(37.11)\end{array}$ & $\begin{array}{c}38 \cdot 31 \\
(38 \cdot 26)\end{array}$ & $39 \cdot 48$ & 39.53 & & -0.63 & -1.80 \\
\hline 15 & $40(s)$ & $\begin{array}{c}38.04 \\
(37.43)\end{array}$ & $\begin{array}{c}38 \cdot 70 \\
(38 \cdot 29)\end{array}$ & $39 \cdot 70$ & $39 \cdot 82$ & $39 \cdot 70$ & -0.66 & -1.66 \\
\hline 16 & $41(s)$ & $\begin{array}{c}37.51 \\
(37.61)\end{array}$ & $\begin{array}{c}38.59 \\
(37.83)\end{array}$ & $40 \cdot 34$ & $40 \cdot 41$ & $40 \cdot 34$ & -1.00 & -2.83 \\
\hline
\end{tabular}

* Direct measurements. Transverse measurements are given in parentheses.

$\dagger$ Measurements in periovarian tissue given in parentheses.

$\ddagger$ Ovulated 22 min after measurements.

$\S$ Ovulated before measurements could be taken.

Temperature of the right common carotid artery.

Before surgery all the animals were anaesthetized with $90 \mathrm{mg}$ sodium pentobarbitone (Nembutal: Abbott) with ether supplement if necessary. Rabbits 1 and 11-13 were also given an epidural injection of $1 \mathrm{mg}$ Leostesin (LEO) for more complete abdominal relaxation.

The experiments took place under three different circumstances: measurements of Rabbits 1-3 were taken in a heated room at $36^{\circ} \mathrm{C}$ at $20 \%$ humidity, Rabbits $4-10$ were placed in an incubator at $25^{\circ} \mathrm{C}$ (Armstrong Care-Ette) humidified by a Heated Humidifier (Ohio Medical Products, Model NO2A) at $100 \%$ relative humidity, while Rabbits 11-16 were examined in a $25^{\circ} \mathrm{C}$ room at $50 \%$ relative humidity.

The abdomen was opened with a $4 \mathrm{~cm}$ incision, one ovary (the right) was identified and the largest follicles were inspected. During measurements the ovary was placed at the level of the incision. The temperature of one follicle and one ovary were measured before and after the organ was replaced in the abdominal cavity in Rabbits 6 and 8 . The temperatures of small, antral follicles ( $<2 \mathrm{~mm}$ in diameter) and large antral follicles ( $>2 \mathrm{~mm}$ in diameter) were measured. The operation lasted from 5 to $59 \mathrm{~min}$ (median: $24 \mathrm{~min}$ ).

In Rabbits 1-10 the ovary and follicles were exposed during the measurements but covered with periovarian tissue between consecutive measurements. In Rabbits 11-16 the ovary was covered at all times with the periovarian tissue even during the measurements. After each measurement the ovary was immediately replaced in the abdominal cavity.

The temperatures of the follicles, the ovary and the surrounding tissue were obtained by thermoelectrodes, and by thermovision. A paired $t$ test was used to test for systematic differences between the follicles and core body and between follicles and ovarian stroma.

Thermoelectrode measurements. The thermoelectrodes (constructed by K.B.) consisted of two thin thermocouple wires of $\mathrm{Ni}$ and $\mathrm{NiCr}$ respectively, welded together at the tip, insulated by $\mathrm{MgO}$ and sheathed in a stainless-steel tube. There were 2 sizes of electrode tubes; a narrow one 
of $0.18 \mathrm{~mm}$ diameter and the other a thicker one of $0.35 \mathrm{~mm}$ outer diameter. The thin electrode was used for measuring the temperature within the follicle, the centre of the ovary (ovarian stroma) and the periovarian tissue. The thicker one was used to measure the temperature of other body tissues: the psoas major muscle, the right carotid artery and the aorta. The sensitive point of the electrodes was situated $0.2 \mathrm{~mm}$ from the tip. The time constant was $5 \mathrm{msec}$, the thermoforce $41 \mu \mathrm{V} /{ }^{\circ} \mathrm{C}$. The heat conduction along the electrodes was tested by introducing the electrodes into a water drop. Heat conduction was negligible when the electrodes were inserted to a distance of at least 5 times the diameter (i.e. $1 \mathrm{~mm}$ for the thin and about $2 \mathrm{~mm}$ for the thick electrode).

The thermoelectrodes were connected to a digital voltmeter (Solartron, A 205) through an electrode selector, which had a resolution of $1 \mu \mathrm{V}$ and an accuracy of $\pm 1 \mu \mathrm{V}$. As reference we used thermobaths of $36^{\circ} \mathrm{C}$ (Rabbits 1-3) or of $25^{\circ} \mathrm{C}$ (Rabbits 4-16). These temperatures were measured with an accuracy of $\pm 0.05^{\circ} \mathrm{C}$.

In all animals the measurements were made by inserting the electrode into the follicles and passing obliquely to the surface of the ovary (direct measurement) through a thin tissue layer (Text-fig. 1, a). In Rabbits 11-16 heat conduction along the electrode in tissue was tested by inserting the electrode transversely through the ovary before entering the follicles (transverse measurement, Text-fig. 1, b). The temperature was measured directly in 40 follicles of 16 ovaries and in 9 of these follicles the temperatures were also measured transversely. Finally, heat loss was compared in two different experimental situations: with the electrode inserted into a follicle (Follicle 22) or into the ovarian stroma (Rabbit 8) while the organ was first outside the abdominal cavity and later replaced within the abdomen without withdrawing the electrode between the measurements.

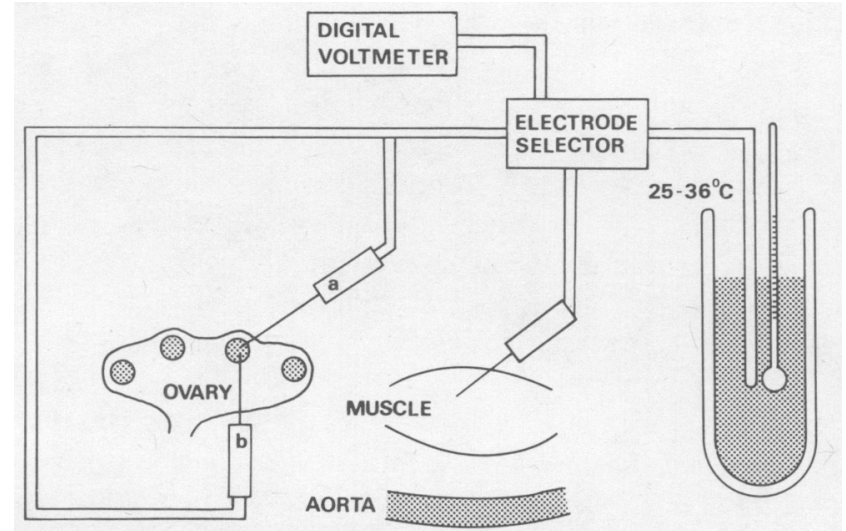

Text-fig. 1. Diagram of the experimental arrangement. The thermoelectrodes were connected to a digital voltmeter through an electrode selector. The follicular temperature was obtained by direct measurement (a) or by transverse measurement (b). The core body temperature was measured in the psoas major muscle or the aorta. The water bath gave the reference temperature.

As core body temperature we used the temperature of the blood of the central arteries (11 animals) or the lowest recording for an abdominal muscle ( 5 animals). The temperature of the arterial blood in the aorta could only be measured at the end of the operation because of the haemorrhage induced (Rabbits 9-16). In Rabbit 8, however, the temperature of the arterial blood was measured continuously during the operation by an electrode inserted into the right carotid artery.

The temperature of the psoas muscle was obtained during the operation for all animals except Rabbit 8. 
Thermovision measurements. In Rabbits 4-10 the follicular temperatures were first measured by thermoelectrodes and then by thermovision using an AGA (Sweden) thermovision 680 , lens $108 / 10^{\circ}$. This AGA system can measure radiating heat differences from a field larger than $2 \mathrm{~mm}^{2}$. A measuring range of $20^{\circ} \mathrm{C}$ divided into 10 temperature steps, each representing $2{ }^{\circ} \mathrm{C}$, was selected. The results were recorded on colour film (polacolor, type 108, Polaroid).

During the measurements the whole ovary was exposed to air for several minutes.

\section{Results}

All the measurements taken are given in Table 1.

The mean temperature \pm s.e.m. of the follicles measured by thermoelectrodes was $2.8 \pm$ $0.2^{\circ} \mathrm{C}$ lower $(P<0.001$, paired $t$ test $)$ than the core body temperature. Within each rabbit the follicular temperatures were lower than that of the body core. Although the actual follicular temperatures differed from animal to animal, the temperature differences between follicle and body core did not vary greatly with the different conditions of measurements (Table 2).

Table 2: Temperature differences, in rabbit follicles, obtained by microthermoelectrodes under different conditions

\begin{tabular}{|c|c|c|}
\hline & $\begin{array}{l}\text { Mean } \pm \text { s.d. temp. } \\
\text { difference }\left({ }^{\circ} \mathrm{C}\right)\end{array}$ & $\begin{array}{l}\text { No. of } \\
\text { follicles }\end{array}$ \\
\hline \multicolumn{3}{|l|}{ Environment } \\
\hline $36^{\circ} \mathrm{C} / 20 \%$ humidity & $-2.45 \pm 1.89$ & 10 \\
\hline $25^{\circ} \mathrm{C} / 100 \%$ humidity & $-3.19 \pm 0.96$ & 21 \\
\hline $25^{\circ} \mathrm{C} / 50 \%$ humidity & $-2.23 \pm 0.51$ & 9 \\
\hline \multicolumn{3}{|l|}{ Tissue cover } \\
\hline None & $-2.95 \pm 1.34$ & 31 \\
\hline Periovarian tissue & $-2.23 \pm 0.51$ & 9 \\
\hline \multicolumn{3}{|l|}{ Duration of operation } \\
\hline$<24 \min$ & $-3 \cdot 10 \pm 1 \cdot 10$ & 18 \\
\hline$>24 \mathrm{~min}$ & $-2.67 \pm 1.28$ & 22 \\
\hline \multicolumn{3}{|l|}{ Thermovision recordings } \\
\hline Performed & $-3.19 \pm 0.96$ & 21 \\
\hline Not performed & $-2.35 \pm 1.38$ & 19 \\
\hline \multicolumn{3}{|l|}{ Ovulation } \\
\hline Induced with Lutal & $-2 \cdot 56 \pm 1 \cdot 16$ & 33 \\
\hline Not induced with Lutal & $-3.86 \pm 1.09$ & 7 \\
\hline \multicolumn{3}{|l|}{ Epidural anaesthesia } \\
\hline Given & $-1.53 \pm 0.96$ & 10 \\
\hline Not given & $-3 \cdot 20 \pm 1.04$ & 30 \\
\hline
\end{tabular}

The size of the antral follicles did not influence the relationship between body core and the follicular temperatures (large, $-2.91 \pm 1.34^{\circ} \mathrm{C}$; small, $-2.67 \pm 1.15^{\circ} \mathrm{C}$ ).

The temperatures of the follicles obtained by direct or tranverse measurements did not differ (direct - transverse: $-0.07 \pm 0.70^{\circ} \mathrm{C}$ (s.d.)).

The temperature of Follicle 22 measured while the ovary was placed outside the abdomen was $0.38^{\circ} \mathrm{C}$ lower than when the ovary was placed inside. The difference of the ovarian stroma temperature when measured outside and inside the abdomen was only $0.05^{\circ} \mathrm{C}$ (Rabbit 8).

The temperature difference between the follicles and the ovarian stroma $\left(-1.4 \pm 0.2^{\circ} \mathrm{C}\right.$, s.e.m.) was significantly different $(P<0.001$, paired $t$ test). This intraovarian difference was similar for large $\left(-1.31 \pm 0.77^{\circ} \mathrm{C}\right.$, s.d. $)$ and small $\left(-1.43 \pm 1.20^{\circ} \mathrm{C}\right.$, s.d. $)$ antral follicles.

Follicles could be identified on the thermovision picture in 4 out of the 7 animals; Follicles $24,26,28,29$ and 31 were measured, visualized and were shown to be one temperature step, i.e. $2^{\circ} \mathrm{C}$, lower than the ovarian stroma (Plate 1). 


\section{Discussion}

The results suggest that the temperature of all antral follicles is lower than the temperature of both the core body and the ovarian stroma. However, these differences could be due to heat conduction, heat convection, heat radiation and evaporation. To eliminate heat conduction along the electrodes these were always inserted more than $1 \mathrm{~mm}$ into a follicle through a tissue layer of at least the same thickness. Furthermore, measurements carried out as direct or transverse measurements gave the same results, indicating that the thermoelectrode was inserted deep enough into the tissue to avoid heat conduction.

To reduce heat convection, heat radiation and evaporation some follicles were covered with periovarian tissue, which always had a higher temperature than the follicles (Table 1). However, there was no significant difference between the covered and uncovered follicles (Table 2) and we conclude that heat convection plays a minor role in the cooling of the follicles. This conclusion is supported by the fact that measurements performed outside and inside the abdominal cavity and in the 3 different environmental conditions were similar.

The temperature of the carotid artery remained constant during the time of operation (Rabbit 8: $28 \mathrm{~min}$ ), implying that the blood temperature of the aorta obtained at the end of the operation is a good indicator for core body temperature. The difference between the lowest temperature of the psoas major muscle and the aorta was $0.09 \pm 0 \cdot 10^{\circ} \mathrm{C}$ (s.d.), showing that the lowest muscle temperature can be used as the core body temperature.

The thermovision pictures also showed that antral follicles were colder than the surrounding ovarian tissue. We therefore conclude that, in spite of the long exposure to air before the picture was taken, the mechanisms which keep the follicle cold overcome eventual heat transfer by air and by the surrounding tissues.

In 4 follicles (Nos 37 and 39-41) bleeding occurred during the transverse measurements. When the temperatures were obtained subsequently by direct measurements the temperature had risen about $0.5^{\circ} \mathrm{C}$, probably as a result of the warmer blood flowing into the follicular cavity.

Temperature measurements obtained by thermistors implanted for 10 days into ovaries of ovulating ewes showed a temperature decrease of $0.2^{\circ} \mathrm{C}$ in the ovary with the ovulating follicle compared to the other one and demonstrated that the temperature of the ovaries was $0 \cdot 14^{\circ} \mathrm{C}$ (mean) higher than that of the aorta (Benoit et al., 1976). Our temperature measurements of the ovary were lower than those of the core body in all circumstances. The discrepant results for ewes and rabbits may be due to factors other than basic species difference. (1) The temperature transmitter in the ewe was placed at random into the ovarian medulla and could have been placed in a field with high vascularization, thus raising the measurements towards the blood temperature. (2) There may have been a tissue reaction around the implanted thermistors in the ewe. Since this was a long-term experiment, the tissues surrounding the transmitter would

\section{PLATE 1}

Thermovision pictures of Follicle 31. The numbers on the right and the left ordinates indicate the measuring range at which the thermovision camera can be adjusted $\left({ }^{\circ} \mathrm{C}\right)$. The interruption on the left ordinate indicates that a measuring range of $20^{\circ} \mathrm{C}$ is selected for these pictures. The temperature capacity $\left(20^{\circ} \mathrm{C}\right)$ is divided into 10 steps, each of which is indicated by an individual colour bar. The step between two bars represents $1 / 10$ of the measuring range, i.e. $2^{\circ} \mathrm{C}$.

Fig. 1. The arrows point at the bright follicle in the dark ovary. The dark fingers of the surgeon holding the ovary are seen.

Fig. 2. The arrows point at the follicle which is green in this picture. The surrounding ovarian tissue is pink which is one step higher in temperature than the green. The fingers holding the ovary are warmer (red). 

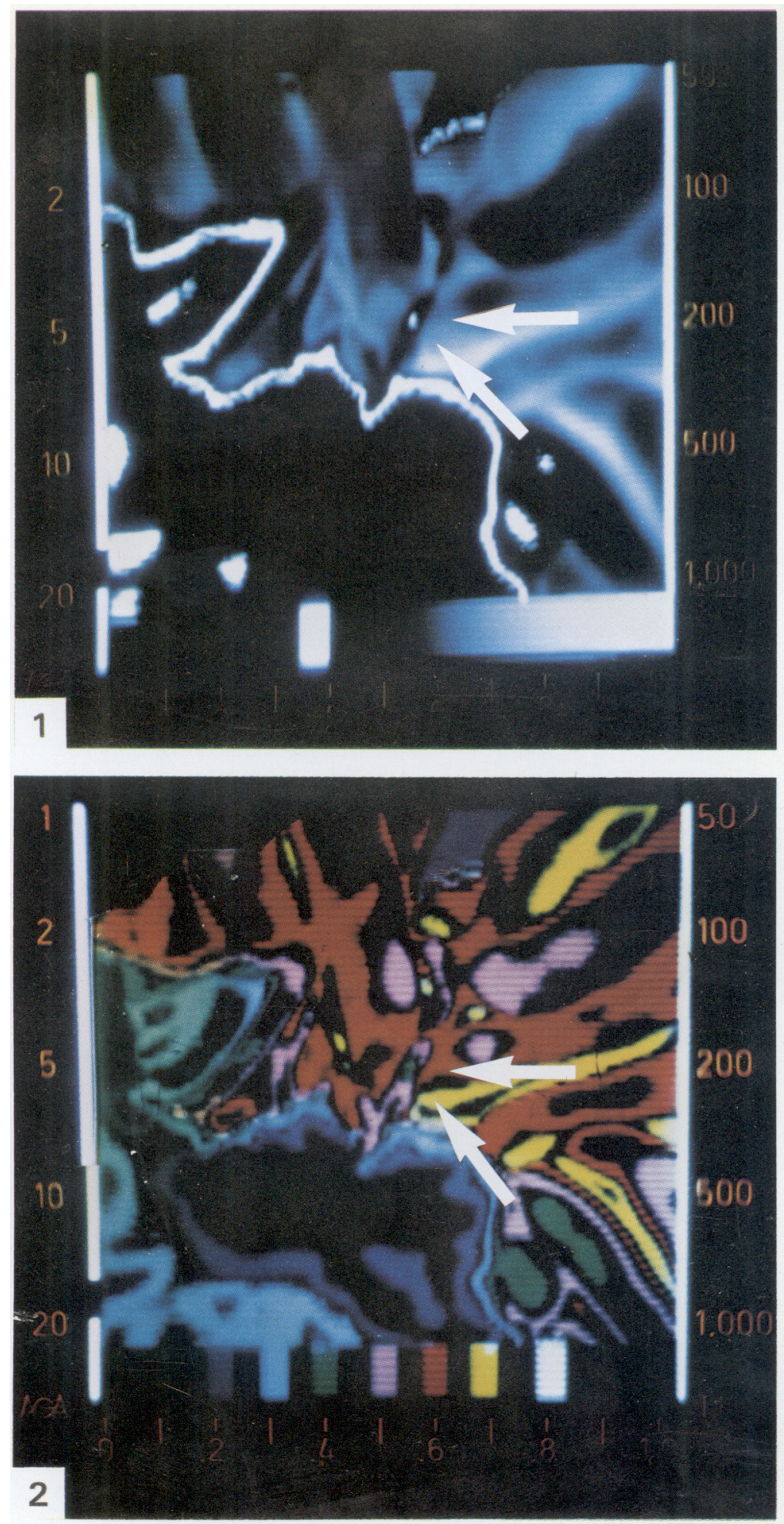
probably react to the implant by increased cell activity and a greater vascularization, resulting in a warmer milieu.

It is known that steep temperature gradients can exist in living tissues (Møller \& Bojsen, 1975). Achievement of the lower temperature in antral follicles is probably not due to a countercurrent distribution of the blood supply to the follicles since the heat transfer by perfusion is presumably too small. It is more likely that an endothermic chemical reaction is involved, caused by a change in the concentrations of macromolecules such as mucopolysaccharides and proteins in the follicular fluid during growth (for review of macromolecules in follicular fluid see McNatty, 1978).

As the relation between core body temperature and the temperature in small and large antral follicles in unstimulated as well as stimulated rabbits is the same, it is suggested that the lower temperature of the follicles is related to the development of the antrum rather than to the preovulatory expansion.

The significance of the colder follicular temperature in relation to resumption of meiosis or survival of the oocytes has yet to be evaluated.

The work is supported by EURATOM contract 120-73-1 BIO-DK.

We thank Th. Dresler (AGA, Copenhagen), O. Lindberg (Technical University of Denmark), A. Bang Mørch, J. Post, E. Rosenløv-Løytved and L. Ahrenst for assistance; Hoechst (Denmark) and J. Starup (University Hospital of Copenhagen) for donating Lutal; AGA (Copenhagen) for lending the thermovision system; and Polaroid (Europe) for financial assistance with the production cost.

\section{References}

Balin, H., Busser, J.H., Fromm, E., Wan, L.S. \& Israel, S.L. (1965) Biotelemetry as an adjunct to the study of ovarian physiology. Fert. Steril. 16, 1-15.

Benoit, H.J., Borth, R., Ellicott, A.R. \& Woolever, C.A. (1976) Periovulatory changes in ovarian temperature in ewes. Am. J. Obstet. Gynec. 124, 356-360.

Blackshaw, A.W. (1977) Temperature and seasonal influences. In The Testis, vol. VI, pp. 517-545. Eds A. D. Johnson \& W. R. Gomes. Academic Press, New York.

Cowles, R.B. (1965) Hyperthermia, aspermia, mutation rates and evolution. Q. Rev. Biol. 40, 341-367.

McNatty, K.P. (1978) Follicular fluid. In The Vertebrate Ovary, pp. 215-259. Ed. E. E. Jones. Plenum Press, New York.
Møller, U. \& Bojsen, J. (1975) Temperature and blood flow measurements in and around 7,12 dimethylbenz(a) anthracene-induced tumors and Walker 256 carcinosarcomas in rats. Cancer Res. 35, 31163121 .

VanDemark, N.L. \& Free, M.J. (1970) Temperature effects. In The Testis, vol. III, pp. 233-312. Eds A. D. Johnson, W. R. Gomes \& N. L. VanDemark. Academic Press, New York.

Waites, G.M.H. (1976) Temperature regulation and fertility in male and female mammals. Israel J. med. Sci. 12, 982-993.

Received 10 December 1979 